largely occupied with miscellaneous analytical work, but chemists are now being appointed to each province, and Dr. Leather will be left free for research work. A potculture house has been built, and drain gauges made.

As might be expected, the mycologist, Dr. Butler, has a very large number of plant diseases to deal with, and the essential preliminary inquiries have been hampered by want of assistants and of a reference herbarium; these difficulties are being steadily overcome.

Mr. Maxwell Lefroy has already rendered considerable service to Indian agriculture by his entomological work; the life-histories of injurious insects are under investigation, and the insecticidal methods suggested have reached the stage of field trials.

The department issues two publications:-(I) the Agricultural Journal of India, a quarterly journal intended for the use of educated Indian agriculturists and general readers interested in agriculture; (2) the Scientific Memoirs of the Department of Agriculture in India.

The former must certainly rank among the most attractive agricultural journals published, if only for its beautifully illustrated descriptions of native husbandry; it also contains accounts, written for the practical man, of the experimental work done at Pusa and elsewhere. The Memoirs are the scientific papers by the members of the Pusa staff; they are widely distributed, and are readily obtainable on application. The system of publishing scientific work in this way has obvious disadvantages, but is said to involve less loss of time than if the papers were sent to a home journal. In most cases purely Indian problems are dealt with; we need only mention the Indian cottons (Gammie), Indian wheat rusts (Butler and Hayman), the composition of Indian rain and dew (Leather), of Indian oil seeds (Leather), Lefroy's papers on the tobacco caterpillar, the castor semi-looper, the rice-bug, and others. This is as it should be; general fundamental problems are best worked out here or in Europe or America, where the number of workers is greater and where it is easy to get into touch with those able to render useful assistance.

E. J. Russell.

\section{WHO BUILT THE BRITISH STONE CIRCLES? I}

STONE circles are prehistoric monuments of a kind which must be familiar to everybody who has seen Stonehenge or any of the other numerous examples to be found in the British Isles. They are to be found chiefly in Great Britain. I believe there are few, if any, examples in Ireland; but a complete chart showing the distribution of stone circles has yet to be made.

The genuine stone circle apparently occurs only in the British Isles. Most, if not all, of the circles found in other countries are merely "retaining walls" left after the tumulus which they retained had been removed. Avenues and dolmens, which are found associated with stone circles in Britain, also occur in other countries. The dolmens especially are widely distributed, generally near the sea coast of the Mediterranean, in the west of France, in the north of Germany, in Denmark and Scandinavia, and in the British Isles.

It would appear, therefore, that the stone circle was an improvement on the dolmen and avenue, not introduced from abroad, but invented in the British Isles.

The stone circles of Britain vary somewhat in the details of their structure. Mr. Lewis divides them into three classes :-

(x) The Dartmoor type, which is found mostly in Cornwall and Devon, and consists of a single circle.

(2) The Aberdeenshire type, of which the distinguishing feature is the large recumbent stone placed between two of the upright stones in the southern part of the circle.

(3) The Inverness type, of which the distinguishing feature is a large domed chamber with an alley leading thereto, covered by a cairn, with entrances towards the south. When the cairn is removed the foundations show three concentric circles.

1 Paper by Mr. J. Gray read before Section $H$ of the British Association at the Dublin meeting, September, rgo8.

NO. 2043, VOL. 79]
These modifications appear to be due to idiosyncrasies of different tribes of the same race. The type is simplest in Devon and Cornwall, and increases in complexity and elaboration in the Aberdeen and Inverness types.

The Distribution of Stone Circles in Britain.

Stone circles do not appear to occur in the eastern counties of England, nor in the north-western counties of the mainland of Scotland. They are found in the greatest number in Cornwall, Devon, South Wales, Shropshire, North Wales, Derbyshire, Cumberland, Wigton, Kirkcudbright, and Dumfries, Arran, Perth, Aberdeenshire, Inverness, Orkney, and Lewis.

Their distribution would be simply explained if we assume that the race who built them first settled in Cornwall and Devon, then migrated up through Wales and Lancashire into south-west Scotland. From thence they passed north to the mouth of the Clyde, crossed through the midlands of Scotland to the mouth of the Tay, whence they moved along the east coast through east Aberdeenshire, then west to Inverness, and after that north through Caithness to the Orkney Isles, the migration finally coming to an end in the Isle of Lewis.

That the direction of the migration was from south to north is supported by the fact that the structure of the circle becomes more elaborate as we move northwards.

\section{Associated Place-names.}

If these stone circles in Britain have all been erected by the same race, one would expect to find some common root in the oldest place-names within the stone-circle area. The river names usually are the oldest place-names, and in Britain, at least, they appear to be derived from the names of tribes, who at some very ancient time settled on their banks. According to Ptolemy's geography, the district now covered by Cornwall and Devon was inhabited during the Roman occupation by a tribe called the Dumnoni. There can be little doubt that this tribal name, by a process of phonetic decay, has been transformed into the modern name of Devon. If confirmation be required of this, it may be pointed out that a tribe also named Dumnoni is mentioned by Ptolemy as occupying the midlands of Scotland, and that they have left the same phonetic transformation of their name in the River Devon, a tributary of the Forth flowing through Ferth, Kinross, and Clackmannan.

There are four rivers Dee within the stone-circle area and none outside. Now it is clear from Ptolemy's geography that the primitive form of Dee was Deva, so that Dee is from the same root as Devon. The following is a list of names of rivers within the stone-circle area, which apparently are phonetic modifications of the same root:Tamar, Taw, Severn, Taff, Teifi, Dovey, Dee (North Wales), Dove, Tame, Dee (affluent of Lune), Devon (Perth), Tay (ancient Tavus), Dee (Aberdeen), Deveron.

There are only very few of these river names outside the circle area, as Thames, Teviot, Tweed.

The stone-circle race from Cornwall to Aberdeen appears to have had one common tribal name, "Devonian," or some phonetic equivalent of that name. No doubt they had other tribal names, but I do not propose to venture further in this direction at present.

\section{Anatomical Characters of the Race with which Stone Circles are Associated.}

I consider that a far more trustworthy guide than philology to the affinities and origin of a race is to be found in the analysis of measurements of its anatomical characters. This assumes, of course, that the average physical characters of a race will remain practically identical for vast periods of time if there is no great change in the racial environment. For example, the dimensions of the pre-dynastic Nagada skulls (measured by Miss Fawcett) have been found to be practically the same as those of the modern Egyptians living in the same district (measured by Dr. C. S. Myers). This means a permanency of average dimensions extending over 8000 to 10,000 years.

A change of environment (even though it is considerable) must, I believe, act for a very long period on a race before it perceptibly changes its racial characters. 
At least, I know of no trustworthy evidence of the physical characters of a race being rapidly changed by its environment, except in modern industrial towns like Glasgow, and such rapid changes in the environment as have been produced by modern industrial development did not occur in the prehistoric times with which this investigation deals.

Assuming, therefore, this principle of the permanency of the average dimensions of a race, I proceed to inquire whether there is any special physical type of man associated with the British stone circles, and to determine, so far as is possible with the material available for comparison, the affinities and origin of this race.

In applying this method of anthropometrical analysis, it should be remembered that a significant difference between two groups of men in a single dimension proves that they cannot possibly belong to the same race. It does not, however, follow with the same degree of certainty that, if there is no significant difference between one or two dimensions, that the races are necessarily the same, but identity is the most reasonable assumption.

In one of the districts in which stone circles are most numerous, namely, in east Aberdeenshire, a very unique type of man has been found in short cists, associated with a special kind of pottery, namely, the "drinking vessel" which Mr. Abercromby has shown to belong to the transition period between the Neolithic and the Bronze age.

The average cephalic index of ten adult male skulls of this short-cist race, measured by Dr. Low, is 85.2 , the average stature is 5 feet 3 inches, the average length of head is $18 \mathrm{I} \cdot \mathrm{I} \mathrm{mm}$., and the average breadth of head is $154: 4$.

Now the remarkable characteristic of this short-cist race is that its physical dimensions differ significantly from all the other groups of prehistoric races of Britain that have as yet been measured.

It differs enormously from the Neolithic race which preceded it. Of these we have two groups, one measured by Thurnam and Davis, having an average cephalic index of 71.9 , and the other by Schuster, having an average cephalic index of 74.7 .

Those who believe that the environment was capable of changing a race with an average index of 74 into a race with an average index of 85 must show that the Neolithic race was transported into an environment which is known, or at least surmised, to be capable of producing broad heads from long heads. It has been surmised that a mountainous environment has this effect, because we generally find broad heads inhabiting the great mountainous regions of Asia and Europe; but we find our short-cist broad heads in Britain, not generally in the mountainous regions, but in the lowlands lying adjacent to the sea coast.

There is no escaping the conclusion, therefore, that the short-cist brachycephals could not possibly have been evolved from the dolichocephalic Neolithic inhabitants of Britain.

There are, however, some prehistoric races in Britain that come much closer to the short-cist men than the Neolithic race.

The Bronze-age men of the round barrows have an average index of 79.3 according to Thurnam and Davis's measurements; another group from the east Yorkshire barrows, measured by Dr. Wright, give an average index of 77.3 ; and a third group, measured by Schuster, give an average index of 76.8 .

Taking Thurnam and Davis's group as being nearest to the short-cist group, I find, on making the necessary statistical calculations, that the odds against short-cist men being a random sample of the round-barrow men are more than 25,000 to $\mathrm{I}$.

All the other prehistoric British groups, such as the Anglo-Saxon or Iron-age groups measured by Myers and Smith, are much further removed than the round-barrow men, so that there can be no question about these belonging to an entirely different race.

The modern Scotch skulls, taken principally from graveyards in the eastern counties of Scotland, and measured by Sir William Turner, evidently belong to much the same type as the round-barrow men, and are undoubtedly of different race from the short-cist men. The mediæval Kentish skulls at Hythe, measured by Dr. Parsons, though apparently belonging to a type not hitherto investigated, and having an average index of $79 \cdot 3$, nevertheless differ widely in their absolute dimensions, more especially in their breadth, from the short-cist skulls.

There is only one small group of five skulls found in Glamorganshire, and measured by Prof. Hepburn, which does not differ significantly in some one dimension from the Aberdeenshire short-cist skulls; and this group evidently belongs to the same race, and was found in a stone-circle district, two stone circles in this district being described in "Archæol. Cambr.," vol. v., 6th series.

Here, then, we have a race differing from all known racial groups, prehistoric or modern, in Britain. In Aberdeenshire and South Wa'les it is found closely associated with stone circles. No other prehistoric race, at least in the Aberdeenshire area, has been found associated with these circles.

The conclusion seems inevitable that the British stone circles were invented and built by a hyperbrachycephalic race of short stature which came from abroad, and apparently settled first, in the early Bronze age, in the district now known as Cornwall and Devon. From thence they migrated through Wales to Scotland by the route already described.

The Affinities and Origin of the Short-cist Race.

Since we can find no affinities to the short-cist race in Britain, we must examine the physical characters of the prehistoric races of the countries from whence migrations into Britain might be supposed to have come.

In Sweden, all the prehistoric races of the Stone, Bronze, and Iron ages have been measured by Retzius, and have average indexes, respectively, of 75, 74.1, and 70 . There can be absolutely no affinity between them and the short-cist men. In Denmark, on the west coast, we have the Borreby type, which closely resembles our roundbarrow men, but differs significantly from the short-cist men.

The most hopeful comparison appeared to be with the short, brachycephalic race in Switzerland, known as the "Disentis" type. This, according to His and Rütimeyer's measurements, has an average index of $86 \cdot 5$, but when the absolute dimensions are taken into consideration and the necessary statistical calculations have been made, $I$ find that the odds against the short-cist men belonging to this type are more than 6000 to $x$.

There appears to be no other likely race in Europe that could have sent, in the Bronze age, emigrants of the shortcist type to Britain.

We must look, therefore, to Asia, the habitat par excellence of brachycephalic man; and Asia Minor is undoubtedly the most likely starting point, at least for a seafaring race.

We have, unfortunately, no measurements of the prehistoric races of Asia Minor, but all authorities appear to be agreed that certain races who were the pioneers of civilisation in the East were brachycephalic, and apparently also of short stature. These brachycephalic races were known by various names, namely, Akkadians, Sumerians, Kassites, Khetan, and Hittites.

We have not the data absolutely to prove that this Turanian race of Mesopotamia and Asia Minor was identical with our short-cist race, but if we fail to find the mother race in Asia Minor we shall have to go much further afield.

There is one small item of positive evidence. The modern Chinese are said to be descended from the Akkadians, and of any type that has been investigated the modern Chinese skull most resembles in size and shape the short-cist skull.

If we should ever find a sufficient number of Akkadian or Hittite skulls to establish their physical type, the question would be settled. In the meantime, the physical evidence, so far as it goes, appears to me to be strongly in favour of the view that our short-cist men were a colony of Akkadians, Sumerians, or Hittites, who migrated to England by sea about 2000 B.C., probably in order to work the Cornish tin mines and the Welsh copper mines.

The Akkadians, according to Conder, in his recent book 
on "The Rise of Man," were, in 2800 B.c., able to coast round Arabia and up the Red Sea to Suez. Why should they not be able a few hundred years later to coast round Africa and Spain and up the Atlantic to Britain?

In 2800 B.c., according to the same authority, the Akkadians were acquainted with silver, gold, bronze, and copper.

One of the most recent theories of the stone circlesthat of Sir Norman Lockyer-is that they were astronomical observatories, by means of which the ancient priests made observations of the sun and stars, and were thereby able to regulate the calendar, to foretell and prepare for the festival seasons of the year, and to tell the time at night.

This theory is in remarkable agreement with the anthropometrical conclusions which I have just submitted to you, for the Akkadians were apparently the first inventors of astronomy. Gudea, the Akkadian prince, who lived about 2800 B.c., has left a stepped pyramid with an observatory on the top. The Akkadians were the astronomical race at the dawn of civilisation, and apparently the ideas of an astronomical race have been embodied in our British stone circles.

\section{THE BRITISH ORNITHOLOGISTS' UNION.}

THE British Ornithologists' Union celebrated its fiftieth anniversary in the rooms of the Zoological Society on Wednesday, December 9. A special meeting was called for the occasion, the president of the union, Dr. F. D. Godman, F.R.S., occupying the chair, and reading an address on the history of the union from its foundation. The idea of forming this society was due, he remarked, to the late Prof. Newton, and was first mooted in his rooms at Cambridge during 1858 ; but it appears finally to have taken shape when, in the following year, at the meeting of the British Association at Leeds, the opportunity was seized of calling together a number of the ornithologists there assembled. The details of the constitution of the union appear to have been then discussed, and a few months later took their final shape. Limited for the first few years of its existence to twenty members, it was at last found expedient to remove this restriction. To-day more than four hundred members are on the roll. From the first it was decided to start a journal, and the name chosen for this was that of the sacred bird of Egypt, the Ibis. The history of the birth and growth of this now celebrated journal was traced later by Dr. Sclater, its first and present editor. After the addresses by the president and Dr. Sclater, gold medals were presented to the four survivors of the original founders, Dr. Godman, Mr. Percy Godman, Dr. Sclater, and Mr. W. H. Hudleston. This pleasant ceremony was followed by an appeal to the members from Mr. Ogilvie Grant, of the British Museum (Natural History), wherein he urged that the union should commemorate its jubilee by sending an expedition to explore the Charles Louis Mountains of New Guinea, probably one of the richest unexplored zoological regions of the world, and this was unanimously agreed upon. The union, of course, could not find the whole of the money necessary for such an undertaking, but a considerable sum has been promised by others interested in this work. The meeting was brought to a conclusion by a dinner held at the Trocadero Restaurant, after which Mr. Boyd Alexander gave a lecture on his recent journey across Africa, and this was followed by a kinematograph exhibition of pictures of bird life.

At a special general meeting, held in the same week, the union considered the report of a committee on a motion brought forward by Mr. H. F. Witherby at the last annual meeting. It was then proposed that the taking or killing of certain birds, or the taking of any egg of certain birds, or the purchase of any such egg knowing it to have been taken in the British Islands by any member of the union, should involve the removal of his name from the list of members. The prohibition with regard to birds was to applv all the year round to the bearded-top golden oriole, hoopoe, marsh harrier, hen harrier. Montagu's harrier, common buzzard, golden eagle, white-tailed eagle, kite, hobby, osprey, common bittern, spoonbill, Kentish plover, avocet, and chough. To the crested tit, snow-bunting, grey-leg goose, dotterel, red-necked phalarope, ruff, whimbrel, black tern, Sandwich tern, roseate tern, great skua, black-throated diver, red-throated diver, and greenshank it was only to apply for the breeding season, but it was to be in force for the eggs of any of the species named. After discussion, it was agreed that if in the opinion of the committee any member shall have personally assisted in or connived at the capture or destruction of any bird, nest, or eggs in the British Isles, by purchase or otherwise, likely in the opinion of the committee to lead to the extermination or serious diminution of that species as a British bird, steps shall be taken, after due inquiry, to remove the offender's name from the list of members.

\section{UNIVERSITY AND EDUCATIONAL INTE LLIGENCE.}

The Most Rev. Dr. Walsh, Roman Catholic Archbishop of Dublin, has been elected Chancellor of the new National University of Ireland.

ThE Berlin correspondent of the Daily Chronicle announces that Prof. Ernst Haeckel, professor of zoology at the University of Jena, is about to retire into private life after forty-eight years' professorial activity. $\mathrm{He}$ will be succeeded by Prof. L. Plate, professor of zoology in the Berlin Agricultural High School.

University College, Reading, has issued a special list of courses in poultry keeping to be given there, with practical training at the college poultry farm, Theale, inclusive of theoretical and practical teaching in this subject. Additional lectures are given by members of the staff on zoology, soils, manures and pastures, chemistry of foods, and bookkeeping.

THE current number of the Empire Review includes an article on the Imperial College of Science and Technology by Dr. Henry T. Bovey, F.R.S., the rector of the college. After giving a brief historical résume of the growth of the Royal College of Science, the Royal School of Mines, and the Central Technical College, Dr. Bovey explains the work of the Departmental Committee appointed by the Board of Education in IgO4, the issue of the charter of July 8, 1907, creating the Imperial College, and the constitution of the governing body. The aims and objects of the new college are then dealt with, and in this part of his article the rector follows very closely the able address he delivered to the students at the opening of the session last October, which was published in full in our issue for October 15 last (vol. lxxviii., p. 613).

THE Department of Agriculture and Technical Instruction for Ireland has arrived at an agreement with the Commissioners of National Education in Ireland for providing means for the training of national-school teachers in elementary experimental science and domestic economy as part of local schemes of technical instruction. The Commissioners are prepared to recognise teachers, who hold certificates of satisfactory attendance at classes approved by the Department, as qualified to give instruction in the subjects named. The Department has circulated copies of the regulations which will govern the classes to be inaugurated and syllabuses of courses of instruction in both subjects. Each course extends over three years, is well graduated, and skilfully adapted to the needs of teachers in elementary schools. The third year's course in elementary experimental science provides instruction in rural economy, and it is so framed that in a few years' time Ireland should possess elementaryschool teachers able and desirous of basing the science teaching of country schools upon the everyday surroundings and experiences of the children.

THe annual prize distribution at the Sir John Cass Technical Institute was held on Wednesday, December 16 , when the chair was taken by Sir Owen Roberts, chairman of the governing body. The prizes were distributed by $\mathrm{Mr}$. Lewis F. Day, after delivering an address, in which he dealt with the mutual dependence of design in art and craft work and their relation to trade, and concluded with NO. 2043, VOL. 79] 